\title{
Playground injuries to children
}

\section{Norton, J Nixon, J R Sibert}

\section{Play value, safety, or both}

$\mathrm{P}$ lay for children has never been more important, particularly as we now know how vital exercise is in promoting health and preventing obesity, both in childhood and also into adult life. Play is also important in establishing social patterns of behaviour that allow children to react to their peers. Public playgrounds form a significant part of the play opportunities for children. It is not surprising therefore that those involved in children's play have been anxious that playgrounds are as popular and provide as many challenges as possible.

Going along with the drive to make public playgrounds as interesting as possible, there was also a drive to make them as safe as possible. This started with concern regarding playground injuries and deaths in the 1970s, particularly following an analysis in Sheffield led by the late Cynthia Illingworth. ${ }^{1}$ This movement led to the introduction of safety features such as impact absorbing surfaces (IAS), changes in equipment entrapment avoidance, height restrictions and guardrails, and changes in materials used in construction of equipment, and design. These changes led to introduction of standards in Britain, ${ }^{2}$ Europe (EN 1176 and 1177), ${ }^{3}$ and Australia. ${ }^{4}$ In the United States, the drive towards safety has been led by the Consumer Product Safety Commission. ${ }^{5}$

It is not surprising however, that the drive for more children's play, and the drive for more safety have been seen to be in conflict and perhaps incompatible. This debate has been heightened by a recent review by Ball, ${ }^{6}$ for the Health and Safety Executive in the UK, suggesting that expensive safety modifications have minimal effect and are not cost effective in terms of reducing injury episodes to children.

This article will attempt to answer this dilemma: what evidence is there to suggest that playground safety features work, and are they worthwhile in preventing serious injuries? We also would like to review the research agenda to improve playground safety. Much of the literature on injuries to children in playgrounds has included minor injuries such as abrasions and lacerations; however, the main injuries of concern are limb fracture and head injury. We will pay particular consideration to them.

\section{REVIEW OF THE LITERATURE}

We have reviewed the literature on playground injury using the approach of a systematic review. We had a clear search strategy focusing on injuries that actually occurred rather than playground characteristics that might in theory cause injury. The detail of the search strategy is included in the Appendix. Papers that did not include injury data and referred to risk or compliance with regulations were excluded. This literature contains only one intervention study ${ }^{7}$ and only one randomised control trial, ${ }^{8}$ which is on a method of safety promotion in schools to promote safe playgrounds and not on actual injuries. Our analysis of the evidence therefore has to be largely descriptive.

We identified 37 reports on playground related injury and death. However, some of these were either review articles with no new data or had purely descriptive data. Details of the papers we have relied on are shown in tables $1-$ 5. We have included one interventional study, ${ }^{7}$ three correlational studies, ${ }^{9-11}$ and five case control studies. ${ }^{12-16}$

The majority of the case series identified did not fulfil the criteria for inclusion in our analysis. The studies were generally non-consecutive case series that did not provide information on a range of factors that would influence the predicted profile of injury. However the descriptive detail included within some of these papers provides a valuable historical perspective when considering the impact of modern safety measures. All the papers that provide some evidence are included in tables $1-5$ : both prior to $1985,{ }^{17-21}$ when safety surfacing was introduced, and after. ${ }^{22-33}$ We are also including reference to a recent detailed population based analysis of playground injuries. ${ }^{34}$

\section{WHAT INJURIES OCCUR? FRACTURES}

Fractures remain among the most common reported fall related injury across the range of reports that date from 1974 to 2001 (tables 1-5). This is despite wide variations in equipment, fall surface, and height of fall. Upper limb fractures are most common; however few studies provide detailed fracture analysis. Ball reports that $71 \%$ of fractures were to the upper limb:22 other studies showed even more fractures of this type. A study by Waltzman and colleagues, ${ }^{31}$ looking solely at fall injuries from monkey bars or jungle gyms reported that supracondylar humeral fractures accounted for $40 \%$ of upper limb fractures. This high percentage may reflect the equipment type, height of fall, or the age of the child. Information was not available on surfacing, but the authors concluded that surface did not influence injury type.

Proximal fracture appears more common in younger children. ${ }^{25}{ }^{30} 32$ The available literature does not inform with regard to the influence of neurodevelopmental status or the interaction between height of fall, type of surface, and fracture type. Lower limb fracture is uncommon. The historical case series by Rivers and colleagues, ${ }^{17}$ published in 1978 , is unusual in that $60 \%$ recorded fractures were to the lower limb. This was a study of hospital admissions, however.

Table 1 Intervention study

\begin{tabular}{|c|c|c|c|}
\hline Title and author & Population & Method of data collection & Conclusions \\
\hline $\begin{array}{l}\text { Sibert et al. Preventing injuries } \\
\text { in public playgrounds through } \\
\text { partnership: a community } \\
\text { intervention study. } 1999^{7}\end{array}$ & $\begin{array}{l}\text { A\&E attendance for playground injury } \\
\text { children 0-14 years. Cases (parks with } \\
\text { increased depth bark and monkey bars } \\
\text { removed)/control (parks unmodified) }\end{array}$ & $\begin{array}{l}\text { A\&E codes. } \\
\text { Questionnaire. } \\
\text { Parks staff recorded park } \\
\text { and equipment use. }\end{array}$ & $\begin{array}{l}\text { Significant }(p<0.001) \text { reduction in } \\
\text { injury rate after removing monkey } \\
\text { bars and increasing depth of bark } \\
\text { beneath equipment. }\end{array}$ \\
\hline
\end{tabular}


Table 2 Correlational studies

\begin{tabular}{|c|c|c|c|}
\hline Title and author & Population & Method of data collection & Conclusions \\
\hline $\begin{array}{l}\text { Sosin D. Surface specific fall } \\
\text { injury rates on Utah school } \\
\text { playgrounds. } 1993^{\circ}\end{array}$ & $\begin{array}{l}157 \text { Utah elementary schools, } \\
\text { kindergarten to grade } 6 .\end{array}$ & $\begin{array}{l}\text { School injury reports. } \\
\text { Enrolment data. } \\
\text { Equipment data from } \\
\text { playground inspection. }\end{array}$ & $\begin{array}{l}\text { Asphalt surfaces associated with } \\
\text { increased risk of total injury. }\end{array}$ \\
\hline $\begin{array}{l}\text { Mott } A \text { et al. Safety of surfaces } \\
\text { and equipment for children in } \\
\text { playgrounds. } 1997^{10}\end{array}$ & $\begin{array}{l}\text { A\&E attendance for playground injury. } \\
0-14 \text { years. } \\
\text { Full details } 301 .\end{array}$ & $\begin{array}{l}\text { A\&E codes. } \\
\text { Questionnaire. } \\
\text { Park staff recorded playground } \\
\text { equipment use. Detailed survey } \\
\text { of equipment. }\end{array}$ & $\begin{array}{l}\text { Significant increase }(p<0.001) \text { in total } \\
\text { injuries on concrete relative to bark or } \\
\text { rubber. Surface, equipment and height } \\
\text { influence injury rates. }\end{array}$ \\
\hline $\begin{array}{l}\text { Laforest et al. Surface } \\
\text { characteristics, equipment height, } \\
\text { and the occurrence and severity } \\
\text { of playground injuries. } 2001^{11}\end{array}$ & $\begin{array}{l}185 \text { injuries on inspected } \\
\text { playgrounds. }\end{array}$ & $\begin{array}{l}\text { Presentations to A\&E in Montreal. } \\
\text { Measurements of height and } \\
\text { energy absorption of surface. }\end{array}$ & $\begin{array}{l}\text { The risk of injury was three times greater } \\
\text { than for } \mathrm{g} \text { level lower than } 150 \text {. Injuries } \\
\text { were } 2.56 \text { times more likely to occur on } \\
\text { equipment higher than } 2 \mathrm{~m} \text { compared } \\
\text { with equipment lower than } 1.5 \mathrm{~m} \text {. }\end{array}$ \\
\hline
\end{tabular}

Table 3 Case-control studies

\begin{tabular}{|c|c|c|c|}
\hline Title and author & Population & Method of data collection & Conclusions \\
\hline $\begin{array}{l}\text { Chalmers D. Height and } \\
\text { surfacing as risk factors } \\
\text { for injury in falls from } \\
\text { playground equipment. } \\
1996^{12}\end{array}$ & $\begin{array}{l}110 \text { cases playground injuries } \\
\text { requiring medical attention. } \\
190 \text { controls - fallen from } \\
\text { equipment but no medical } \\
\text { attention required. }\end{array}$ & $\begin{array}{l}\text { School staff/hospital records. } \\
\text { Interview with child/parents } \\
\text { Site visits }\end{array}$ & $\begin{array}{l}\text { The risk of injury increased with heights } \\
\text { greater than } 1.5 \mathrm{~m} \text { (OR } 4.14 \text { ) and with } \\
\text { non-IAS (OR } 2.28 \text { ). Falls from non- } \\
\text { compliant equipment increased risk of } \\
\text { injury. }\end{array}$ \\
\hline $\begin{array}{l}\text { Mowat DA et al. Case } \\
\text { control study of risk factors } \\
\text { for playground injuries } \\
\text { among children in Kingston } \\
\text { and area. } 1998^{13}\end{array}$ & $\begin{array}{l}45 \text { cases } A \& E \text { attendance } \\
\text { with playground injury. } \\
\text { Age/sex matched controls non-injury } \\
\text { and non-playground injury. }\end{array}$ & $\begin{array}{l}\text { CHIRPP surveillance programme. } \\
\text { Telephone interview. } \\
\text { Safety audit data/hazard } \\
\text { identification. }\end{array}$ & $\begin{array}{l}\text { Injury was associated with inappropriate } \\
\text { surfaces (OR 21), appropriate surface of } \\
\text { inadequate depth (OR 18.2) and } \\
\text { inadequate guard rails (OR 6.7). }\end{array}$ \\
\hline $\begin{array}{l}\text { Macarthur } \mathrm{C} \text { et al. Risk } \\
\text { factors for severe injuries } \\
\text { associated with falls from } \\
\text { playground equipment. } 2000^{15}\end{array}$ & $\begin{array}{l}\text { A\&E/Admissions Toronto } \\
\text { Hospital for Sick Children } \\
\text { after fall from playground } \\
\text { equipment. } 18 \mathrm{mth}-14 \text { years }\end{array}$ & $\begin{array}{l}\text { Hospital records. } \\
\text { CHIRPP. } \\
\text { Telephone interview. } \\
\text { Site visit. }\end{array}$ & $\begin{array}{l}\text { Falls from }>1.5 \mathrm{~m} \text { had a } 2 \text {-fold } \\
\text { increased injury risk. As most children } \\
\text { fell onto modern surfaces the role of } \\
\text { surface was not evaluated. }\end{array}$ \\
\hline $\begin{array}{l}\text { Laforest et al. Severity of fall } \\
\text { injuries on sand or grass in } \\
\text { playgrounds. } 2000^{1 / 4}\end{array}$ & $\begin{array}{l}930 \text { children } 1-14 \text { y attending } \\
2 \text { A\&E units after falling from } \\
\text { play equipment. }\end{array}$ & $\begin{array}{l}\text { A\&E database. } \\
\text { Telephone questionnaire. } \\
(91 \%) \text { response. }\end{array}$ & $\begin{array}{l}\text { Grass is not a safe surface for play } \\
\text { equipment. The adjusted risk of an IAS } \\
>2-3 \text { was } 1.7 \text { times higher on grass } \\
\text { than sand. }\end{array}$ \\
\hline $\begin{array}{l}\text { Petridou et al. Injuries in } \\
\text { public and private playgrounds: } \\
\text { the relative contribution of } \\
\text { structural, equipment and human } \\
\text { factors. } 2002^{16}\end{array}$ & $\begin{array}{l}777 \text { injuries in public and } \\
\text { private playgrounds in Athens. } \\
\text { Public playgrounds have more } \\
\text { equipment, usually of greater } \\
\text { height, with less resilient surfaces. }\end{array}$ & $\begin{array}{l}\text { Injury surveillance in the } \\
\text { Accident Department. }\end{array}$ & $\begin{array}{l}2.2 \text { times higher risk for an injury in } \\
\text { public than in private playgrounds ( } 95 \% \\
\text { confidence interval } 1.61-3.07 \text { ). With } \\
\text { eight times higher odds for concussion. }\end{array}$ \\
\hline
\end{tabular}

Table 4 Case series prior to 1985 (and modernisation)

\begin{tabular}{|c|c|c|c|}
\hline Title and author & Population & Method of data collection & Conclusions \\
\hline $\begin{array}{l}\text { Illingworth ef al. Injuries } \\
\text { caused by playground } \\
\text { equipment. } 1975^{1}\end{array}$ & $\begin{array}{l}200 \text { Non-sequential } \\
\text { attendances to Sheffield } \\
\text { Children's A\&E. }\end{array}$ & $\begin{array}{l}\text { Proforma completed. } \\
\text { Injury graded. }\end{array}$ & $\begin{array}{l}\text { Narrative study of the injury profile seen on playgrounds. } \\
\text { Fractures accounted for } 26.5 \% \text { total injury; this included } 5 \\
\text { skull fractures. } 12 \text { children had concussion }\end{array}$ \\
\hline $\begin{array}{l}\text { Rivers } R \text { et al. Falls from } \\
\text { equipment as a cause of } \\
\text { playground injury. } 1978 .{ }^{17}\end{array}$ & $\begin{array}{l}\text { Trauma admissions to } \\
\mathrm{UCH} \text { in London. }\end{array}$ & $\begin{array}{l}\text { Note review and } \\
\text { questionnaire. }\end{array}$ & $\begin{array}{l}40 \text { cases described including } 29 \text { head injuries. These were } \\
\text { severe with } 3 \text { fractures and } 8 \text { LOC. Severe head injury } \\
\text { associated with non-IAS. }\end{array}$ \\
\hline $\begin{array}{l}\text { Frost J. Making playgrounds } \\
\text { safe for children. } 1979^{18}\end{array}$ & USA. & NEISS data. & Discussion re playground safety regulations. \\
\hline $\begin{array}{l}\text { Oliver T et al. Playground } \\
\text { equipment and accidents. } \\
1981^{19}\end{array}$ & $\begin{array}{l}\text { Northern Sydney. } \\
\text { Children 2-12 years. } \\
\text { Limited data on } 162 \text { injuries. }\end{array}$ & Surveys of 7 A\&E units. & $\begin{array}{l}\text { Falls to hard ground were identified as the prime mechanism } \\
\text { of injury. } 24 \% \text { injuries were fractures, these comprised skul } \\
\text { and limb fractures. }\end{array}$ \\
\hline $\begin{array}{l}\text { Christensen S. Accidents with } \\
\text { playground equipment } 3 \text {. } \\
1982^{20}\end{array}$ & $\begin{array}{l}\text { A\&E attendance Aarhus. } \\
1-14 \text { years. }\end{array}$ & $\begin{array}{l}\text { Questionnaire A\&E } \\
\text { attendance Municipal } \\
\text { hospitals in Aarhus. }\end{array}$ & $\begin{array}{l}466 \text { children. Injury severity increased with increasing fall } \\
\text { height. The available surface should influence the maximum } \\
\text { fall height. }\end{array}$ \\
\hline $\begin{array}{l}\text { Boyce W. Epidemiology of } \\
\text { injuries in a large urban school } \\
\text { district. } 1984 .^{21}\end{array}$ & Tuscon school district. & School nurse data survey. & $\begin{array}{l}\text { Playground injuries are relatively severe when compared to } \\
\text { all injuries relating to sports and leisure equipment use. } \\
\text { Younger children more likely to be injured on playgrounds. }\end{array}$ \\
\hline
\end{tabular}


Table 5 Case series after 1985

\begin{tabular}{|c|c|c|c|}
\hline Title and author & Population & Method of data collection & Conclusions \\
\hline $\begin{array}{l}\text { Ball D. Playground injuries: } \\
\text { a scientific appraisal of } \\
\text { popular concerns. } 1991^{22}\end{array}$ & $\begin{array}{l}13 \text { A\&E units in } \\
\text { England \& Wales. }\end{array}$ & A\&E data LASS. & $\begin{array}{l}\text { Total of } 1812 \text { cases recorded. Fractures accounted for } \\
16.5 \% \text { injuries, concussion for } 1.4 \% \text {. Playground injuries } \\
\text { are relatively uncommon and certain safety measures may } \\
\text { not be justifiable on cost terms. }\end{array}$ \\
\hline $\begin{array}{l}\text { Edwards D. Tarzan swings. } \\
\text { A dangerous new epidemic. } \\
1991 .{ }^{23}\end{array}$ & $\begin{array}{l}\text { A\&E attendance } \\
\text { Sheffield. }\end{array}$ & Questionnaire. & $\begin{array}{l}29 \text { children with fractures, } 90 \% \text { to the upper limb. } \\
\text { Homemade rope swings are associated with serious } \\
\text { fractures. }\end{array}$ \\
\hline $\begin{array}{l}\text { Bond M. The risk of childhood } \\
\text { injury on Boston's playground } \\
\text { equipment and surfaces. } 1993^{24}\end{array}$ & $\begin{array}{l}\text { Playgrounds in Boston. } \\
47 \text { in final sample. }\end{array}$ & $\begin{array}{l}\text { Single observer site } \\
\text { visit/checklist. }\end{array}$ & $\begin{array}{l}\text { Boston's playgrounds are not adequately maintained or } \\
\text { designed to reduce clear hazards. }\end{array}$ \\
\hline $\begin{array}{l}\text { Mott A et al. Patterns of injuries } \\
\text { to children on public playgrounds. } \\
1994 .^{25}\end{array}$ & $\begin{array}{l}\text { A\&E attendances, } \\
\text { 0-14 years, } \\
\text { Cardiff UK. }\end{array}$ & $\begin{array}{l}\text { Questionnaire. } \\
\text { Playground survey. } \\
\text { Playground inspectors } \\
\text { recorded utilisation. }\end{array}$ & $\begin{array}{l}\text { Fewer injuries overall than predicted on modern surfaces } \\
\text { (not statistically significant). The profile of injury differed } \\
\text { between surfaces. }\end{array}$ \\
\hline $\begin{array}{l}\text { Briss } P \text { et al. Injuries from falls } \\
\text { on playgrounds. Effects of day } \\
\text { care centre regulation and } \\
\text { enforcement. 1994. }\end{array}$ & $\begin{array}{l}\text { Day care centres } \\
\text { across USA. } \\
\text { Under } 5 \mathrm{~s} .\end{array}$ & $\begin{array}{l}\text { Probability sample. } \\
\text { Telephone survey. }\end{array}$ & $\begin{array}{l}\text { Injury rates lower on optimal but not on potentially resilient } \\
\text { surfaces. The benefit of optimal surfaces increases with } \\
\text { increasing height. }\end{array}$ \\
\hline $\begin{array}{l}\text { Lillis K. Playground injuries } \\
\text { in children. } 1997 .^{27}\end{array}$ & $\begin{array}{l}\text { CHIRRP data. } \\
\text { Sample A\&E units }\end{array}$ & CHIRRP data extraction. & $\begin{array}{l}289 \text { injuries, fractures accounted for } 28 \% \text { and concussion } \\
\text { for } 3 \% \text {. Climbing frame injuries accounted for } 2 / 3 \text { hospita } \\
\text { admissions, most with UL fracture. Numbers were } \\
\text { insufficient to comment on effect of surface (and no height } \\
\text { data). }\end{array}$ \\
\hline $\begin{array}{l}\text { Mack M. A descriptive analysis } \\
\text { of children's playground injuries } \\
\text { in the USA. 1990-94 }\end{array}$ & $\begin{array}{l}\text { Neiss data. } \\
90 \text { emergency units } \\
\text { in USA. }\end{array}$ & $\begin{array}{l}\text { Neiss database samples } \\
90 \text { A\&E units and } \\
\text { produces estimates. }\end{array}$ & $\begin{array}{l}\text { Neiss playground injury statistics can identify how and } \\
\text { where children are injured, increase understanding and } \\
\text { guide attempts to decrease injuries. }\end{array}$ \\
\hline $\begin{array}{l}\text { Mayr J. Playground accidents. } \\
\text { 1995. }{ }^{29}\end{array}$ & $\begin{array}{l}1-15 \text { years attending } \\
\text { Dept Paediatric Surgery. }\end{array}$ & $\begin{array}{l}\text { Postal questionnaire } \\
\text { (28\% replied }=103 \text { ). }\end{array}$ & $\begin{array}{l}\text { Low response rate but } 31 \% \text { injuries were fractures or } \\
\text { concussions, most on non-IAS. }\end{array}$ \\
\hline $\begin{array}{l}\text { Chalmers D, Playground injury: } \\
\text { the kids are still falling for it. } \\
1999^{30}\end{array}$ & $\begin{array}{l}\text { Hospital admissions } \\
\text { in NZ. }\end{array}$ & $\begin{array}{l}\text { School surveys } 1997 . \\
\text { NZ health information } \\
\text { service statistical data. }\end{array}$ & $\begin{array}{l}\text { Trend for increased reporting of minor injuries. Fewer } \\
\text { serious injuries seen on modern surfaces. }\end{array}$ \\
\hline $\begin{array}{l}\text { Waltzman } M \text { et al. Monkey } \\
\text { Bar injuries. Complications } \\
\text { of play. } 1999 . .^{31}\end{array}$ & $\begin{array}{l}\text { Paed admission related } \\
\text { to monkey bar falls to } \\
\text { Boston trauma centre. } \\
\text { Range } 20 \text { mth to } \\
12 \text { years. }\end{array}$ & $\begin{array}{l}\text { Retrospective chart review. } \\
\text { Telephone survey. }\end{array}$ & $\begin{array}{l}\text { High percentage of fractures }(61 \%) \text { reported. The majority } \\
\text { were upper limb with supracondylar fractures accounting } \\
\text { for } 40 \% \text { total. Fracture type was age dependent. } \\
\text { Children under } 4 \text { more likely to sustain long bone fracture. } \\
\text { Surface did not influence injury type but no data on height. }\end{array}$ \\
\hline $\begin{array}{l}\text { Bernardo LM. Playground injuries in } \\
\text { children. A review and Pennsylvania } \\
\text { trauma centre experience. } 2001^{32}\end{array}$ & $\begin{array}{l}\text { Admissions to } \\
\text { Pennsylvania trauma } \\
\text { centres. }\end{array}$ & Proforma. & Nurses can advocate for playground safety. \\
\hline $\begin{array}{l}\text { CPSC Playground Injuries treated in US } \\
\text { hospital emergency rooms. } 2001^{33}\end{array}$ & $\begin{array}{l}\text { Admissions to } \\
\text { emergency rooms. }\end{array}$ & $\begin{array}{l}\text { Information direct from } \\
\text { emergency rooms. }\end{array}$ & Typical example of a yearly publication. \\
\hline $\begin{array}{l}\text { Ball D. Playgrounds: risks, benefits and } \\
\text { choices. Contract research report. } 426 \text { / } \\
\text { 2002. Health and safety Executive } 2002\end{array}$ & $\begin{array}{l}\text { Presentations to LASS } \\
\text { from a selection of } \\
\text { Accident Departments. }\end{array}$ & $\begin{array}{l}\text { From LASS Data } \\
\text { Department of Trade } \\
\text { and Industry. }\end{array}$ & Information 1988-98. \\
\hline
\end{tabular}

\section{WHAT INJURIES OCCUR? HEAD INJURY}

Severe head injury resulting in skull fracture, intracranial haemorrhage, or neurological disturbance requiring admission to hospital is rare on modern playgrounds. ${ }^{34}$ Impact absorbing surfaces were introduced to prevent head injury. Earlier case series before the introduction of these surfaces make clear narrative reference to complex skull fractures and intracranial injury. The paper by Cynthia Illingworth and her colleagues in $1975^{1}$ analysed 200 non-consecutive presentations to an accident department. In this Sheffield study, given that a child was injured in a playground, there was a $6 \%$ chance of a playground injury resulting in skull fracture or concussion. There are no clear definitions of the severity of head injury in this paper, but there are written descriptions of injuries. These include "an extensive occipital fracture with loss of consciousness", "a drowsy girl with a large fracture of the parietal bone", "two severe skull fractures" and "a serious injury with a fracture of the occiput".

Rivers and colleagues ${ }^{17}$ described 40 children admitted to hospital (University College Hospital in London) between 1974 and 1977 with playground related injury. This was a study of hospital admissions however, which may have influenced the fractures recorded. The majority (85\%) of injuries resulted from falls and the majority of these (26 of 27 where surface was recorded) were on to concrete, tarmac, or packed earth. Twenty nine of these children had head injuries, of which eight children were unconscious, three had skull fracture, and three had neurological symptoms lasting more than 48 hours.

Oliver and colleagues ${ }^{19}$ surveyed playground related A\&E attendances between 1978 and 1979. This paper contains limited data on 162 injuries. Falls to hard ground were identified as the prime mechanism of injury. Nearly a quarter $(24 \%)$ of the injuries were skull and limb fractures. Additional information on fracture type was limited to three brief case histories describing two severe skull fractures and a humeral fracture, all requiring hospital admission.

All this suggests that before the introduction of safety features there 
were definite serious head injuries. The definition of concussion or head injury is not clear in many of the series in our review and therefore definite conclusions are difficult to draw. However, it does appear that serious head injuries are rare on modern surfaces.

\section{RISK WITH SURFACES}

A number of studies have linked overall injury rates and surface. One correlational study that looked at overall injuries on modern surfaces and tarmac/concrete ${ }^{10}$ reported 330 children aged 1-14 injured on public playgrounds. It found that rubber playgrounds had half the risk of bark and a fifth of that of concrete $(p<0.001)$. Chalmers $^{12}$ found similar results; the odds of being injured in a fall on a non impact absorbing surface was 2.28 times that of a fall onto an impact absorbing surface. Laforest and colleagues, ${ }^{14} \mathrm{com}$ paring sand and grass, found that the adjusted risk of injury was 1.7 times more likely on grass relative to sand. Mowat and colleagues, ${ }^{13}$ again looking at overall injuries in a case-control study found that multivariate analysis showed a strong association between injuries and use of inappropriate surfacing; Sosin' found that the injury rate on asphalt was six times that on sand.

Therefore, if overall injuries are considered, there are significant differences between impact absorbing surfaces and harder surfaces such as tarmac, concrete, or grass. However, what is the situation with fractures? Macarthur and colleagues, ${ }^{15}$ in a case-control study, compared severe (mainly fractures) and minor injuries (mainly facial lacerations). There were no significant differences between the surfaces. Similarly bark surfaces were not significantly protective of arm fractures relative to concrete in other studies. ${ }^{10}$ The conclusion that safety surfaces are ineffective in preventing arm fractures is also confirmed by the lack of improvement in the proportion of fractures in playground injury surveillance with time.

There are biomechanical reasons why safety surfaces may not protect against arm fracture. Experimental models suggest that the current surfaces may be useful in attenuating forces from impacts involving falls from a standing height. However, in higher falls, such as falls from equipment in playgrounds, the surface is not successfully attenuating all of the force components, which result in fracture. ${ }^{35}$

\section{RISK WITH HEIGHT}

The relation between height of fall and injury has been confirmed by a number of studies. Macarthur and colleagues ${ }^{15}$ found significant difference in height between severe and minor injuries. Briss and colleagues found injury rates significantly increased with height of the tallest piece of equipment on the play-

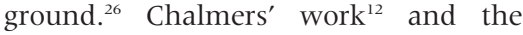
work of Mott and colleagues, ${ }^{10}$ found that heights below 1.5 metres were protective. Children injured in falls from playground equipment will be more likely to have fallen from greater heights than children with minor injuries (or no injuries).

There have been few studies looking at height of equipment and injuries to children in playgrounds. There are real research questions, in particular establishing whether the increased heights at 4 metres in the European standards really do present increased risks to children.

\section{RISKS WITH EQUIPMENT}

There have been considerable improvements in the design of playground equipment over the years. Swings, for instance, have had impact absorbing seats, and ideally fences to prevent children running into them. This has resulted in swings being among the safest pieces of equipment in the playground, ${ }^{10}$ whereas in 1976 a swing was reported to cause a massive subgaleal haemorrhage. ${ }^{37}$ Similarly slides are now attached to mounds or natural slopes.

On the other hand, monkey bars or horizontal ladders seem to offer increased risks to children. ${ }^{10}{ }^{31}$ This is probably because of the upper body strength needed to use them.

\section{HEIGHT AND SURFACE}

The height that a child can fall, the surface fallen to, and the interaction of the two have been identified as contributing to injury related to playground equipment. Standards in the USA, Canada, and Australia, recognise a nexus between the two and have produced standards for the measurement of the impact attenuation properties of different surfaces. ${ }^{46}$ This approach has the advantage of objective measurement and/or moving the debate from suitability of different types of loose fill surface to what is a suitable level of measurement to prevent or reduce injury. Compliance of a surface can be measured with consideration of the height of the equipment, and the impact attenuation properties of the surface. The measure used is a calculated head injury criterion (HIC) derived from forces measured in adult seat belt experiments decades ago. Recent findings linking accelerometer testing of surfaces with injuries to children following falls from horizontal ladders suggest that the levels of $200 \mathrm{~g}$ (or HIC 1000) are not sufficient to be protective for fractures, and that the standards in USA, Australia, and Canada might need to be revisited as further data on real injuries from real falls become available (Nixon et al, unpublished data). Chalmers $^{12}$ estimated some $10 \%$ of attendances at hospital following playground injury were attributable to noncomplying surfaces, while $5.6 \%$ were attributed to the interaction between the surface and the height of the equipment.

\section{INTERVENTION STUDIES}

There have been only two intervention studies on playground injuries reported in the literature. An intervention in Cardiff increased bark depth in five playgrounds and replaced monkey bars with a rope climbing frame in one of them. These playgrounds were compared with 14 others, where no changes were made. There were significantly fewer injuries when taken as a whole, and in the playground where the monkey bars were replaced. The reduction in injuries in the four playgrounds where just the bark depth was increased was not significant. This was essentially an opportunistic study; the Council was making changes which were able to be monitored.

The other study was a community intervention trial in New Zealand ${ }^{8}$ where 24 schools were randomised to a programme to encourage them to improve playground hazards at schools. The programme was effective.

EXPOSURE OF CHILDREN TO RISK Three measures of exposure to playground surfaces and play have been reported. Injuries to children in childcare centres in Atlanta have been expressed as injuries per 100000 hours spent in childcare. ${ }^{26}$

Another approach to exposure used number of children and time spent playing over different play surfaces. ${ }^{9}$ The measure translated into an injury rate over grass of 12/10 000 child years. A third method of determining "exposure" was to count the number of children playing in each park visited by park inspectors. ${ }^{11}$ This measure, while convenient, assumed that all play equipment was used equally by the children in the park, and examined children playing over different surfaces rather than the equipment played on. Recent studies in Australia ${ }^{38}$ show that children exhibit different levels of play on different types of equipment and in the different settings of parks and schools.

From observation studies each horizontal ladder was used 2.6 times more often than each piece of climbing equipment in schools, while each horizontal ladder was used 7.8 times more 
than each piece of climbing equipment in a sample of public parks. Slides were used 4.6 times more than climbing equipment in parks and 1.2 times more in public schools.

\section{PLAY VALUE VERSUS SAFETY}

Two interests have been identified in educational literature: the need for safety in the playground, and the need to provide a variety of developmental and educational experiences for children. The risk of playground injury is small among preschool children; understandably the main focus for this group is on play experience, and safety advice is directed at supervision and surfaces. $^{39}{ }^{40}$ While some level of supervision is expected in schools, playgrounds in public parks cater for a much wider age range among children, and there is little or no supervision.

Children's outdoor play in schools has also been reported to be under threat. Reasons put forward include the following: the time could be better spent on academic pursuits; playground injuries promote litigation; children are at an increased risk of coming in contact with threatening strangers; and teachers and volunteers are less willing to supervise play activities. The value of play to children's physical and mental development is not challenged; however, it must also be balanced with the child's right for minimal risk to disabling injury. ${ }^{41}$ Head injury or serious fractures with lifelong consequences should not be considered part of growing up.

\section{PLAY MORTALITY}

Although injuries are the leading cause of mortality for children over 1 year of age, all the evidence is that very few children die in playgrounds..$^{43} 44 \mathrm{~A}$ review of the CHIRPP database (Canada) by Lillis et al during 1990-91 did not identify any fatal playground accidents. ${ }^{27}$ Chalmers' study in New Zealand placed the risk at 0.15/100 000 for playground related death. ${ }^{12}$ In the northern hemisphere Ball and King assumed one death per annum (1985) in the United Kingdom. ${ }^{22}$

There have been a number of reports ${ }^{45}{ }^{46}$ from the United States based on data from the Consumer Product Safety Commission, the most comprehensive being published in 2001.$^{47}$ From January 1990 to August 2000, CPSC received reports of 147 deaths to children younger than 15 that involved playground equipment ( 15 per annum). In the 128 incidents for which the location was reported, $90(70 \%)$ occurred in home locations and $38(30 \%)$ in public playgrounds. Over half of these deaths involved unintentional hanging, primarily from ropes, shoestrings, clothing, or homemade swings. A review of the DTI/ LASS (UK) database from 1978 to 2000 did not reveal any deaths coded to playground sites. Although accidents are a leading cause of mortality in childhood, the risk of playground death is small. The predominant cause of death in the current literature is strangulation, rather than head injury due to falls or collision.

\section{THE WAY FORWARD AND CONCLUSIONS}

Injuries to children in playgrounds is a complex subject. They are many factors that influence them, including the environment of the playground, the behaviour of the child, and frequency of use. This article has focused mainly on environmental factors.

Many of the studies that have investigated playground injuries have described overall injuries. This may have resulted in insufficient focus on the injuries that really matter: those to the head and fractures. A historical review implies that there were serious head injuries before the introduction of modernisation and safety surfacing. Indeed the prevention of head injuries was the reason why safety surfacing was introduced. There are very few head injuries now in modern playgrounds. We therefore believe that safety surfacing is likely to be effective in preventing head injuries and should be continued.

There is also evidence that safety surfacing has prevented overall injuries. However, it does not seem to protect against fractures of the arm. The next step therefore should be to develop surfaces that protect against limb fractures while not compromising safety from head injury.

There are difficulties in implementing intervention studies to prevent playground injuries. There needs to be a cooperative local council (or school). Changes are unlikely to be made just for a scientific study. Despite these difficulties, there are unanswered questions about playground injuries, and further well designed studies will be needed to continue to reduce the risk of injuries in playgrounds. This will require ongoing surveillance.

Although there are still challenges, particularly the prevention of arm fractures, modern playgrounds are safer now than they were 35 years ago. They are still popular with children and mostly provide good play experience for them. They do not need fall heights of over 4 metres, and concrete surfaces to be exciting for children. If they are seen to be safe by parents, they will allow their children to play. This will mean safety for the children and good play experience as well.
Arch Dis Child 2004;89:103-108. doi: 10.1136/adc.2003.013045

Authors' affiliations

C Norton, J R Sibert, Department of Child

Health, University of Wales College of Medicine, Llandough Hospital, Penarth CF64 2XX, Wales, UK

J Nixon, Department of Child Health, University of Queensland, Paediatrics and Child Health, Royal Children's Hospital, Herston, QLD 4029, Brisbane Australia

Correspondence to: Prof. J R Sibert, Department of Child Health, University of Wales College of Medicine, Llandough Hospital, Penarth CF64 2XX, Wales, UK; sibert@cf.ac.uk

\section{APPENDIX}

\section{Search strategy}

- Electronic bibliographic databases. Medline via OVID (1966-2000), Premedline 2001, Embase, Cinahl, Science citation index, Health Star.

- Reference list review of key papers.

- Hand searching key journals, e.g. Injury Prevention.

- Grey literature review via SIGLE (System for information on Grey literature), HMIC (Health Management Information Consortium) CD-ROM.

- National Research register review.

- Manufacturers and trade organisations -ILAM, Playing Fields Association.

- Internet sites, e.g. CPSC (Consumer Product Safety Commission).

\section{Search terms employed}

Playgrounds or play* or leisure or monkey bars or swings or slides or "climbing frames" and Injuries or fall or fracture or accident and Prevention or prevent* ${ }^{*}$ or surfaces or surface*.

\section{Inclusion criteria}

All study designs were initially considered. Papers referring to public, school, and home/improvised playground equipment were included. Papers that did not include injury data and referred to risk or compliance with regulations were excluded. Papers referring to sport play activities not involving playground equipment and purely behavioural studies were excluded.

Papers with a more restricted focus, such as epidemiology of head injury or fracture were retained for information and reference review.

Papers were selected that provided information on injuries incurred by children in a playground setting. Papers with a more restricted focus, such as epidemiology of head injury were retained for information and reference review. 


\section{REFERENCES}

1 Illingworth C, Brennan P, Jay A, et al. 200 injuries caused by playground equipment. $B M$ 1975;4:332-4

2 Heseltine P, Holborn J, Wenger J. Playground management and safety. London: National Playing Fields Association, 1989.

3 Davies R, Heseltine P. A guide to EN1 176\&1177. ROSPA/API, 2000

4 Standards Australia. AS/NZ 4422: 1996.

Playground surfacing-specifications, requirements and test method. Report no. AS/ NZS 4422: 1996. Sydney: Standards Australia, 1996

5 US Consumer Product Safety Commission. Handbook on public playground safety, US Consumer Product Safety Commission, 1999.

6 Ball D. Playgrounds: risks, benefits and choices. Contract research report. 426/2002. Health and Safety Executive, 2002.

7 Sibert JR, Mott A, Rolfe K, et al. Preventing injuries in public playgrounds through partnership between health services and local authority: community intervention study. BMJ 1999;318:1595.

8 Roseveare C, Brown JM, Barclay Mclntosh JM, et al. An intervention to reduce playground equipment hazards. Inj Prev 1999;5:124-8.

9 Sosin D. Surface specific fall injury rates on Utah school playgrounds. Am J Public Health 1993:83:733-5.

10 Mott A, Rolfe K, James R, et al. Safety of surfaces and equipment for children in playgrounds. Lancet 1997:348:1874-6.

11 Laforest S, Robaitaille Y, Lesage D, et al. Surface characteristics, equipment height, and the occurrence and severity of playground injuries. Inj Prev 2001;7:35-40.

12 Chalmers D. Height and surfacing as risk factors for injury in falls from playground equipment. In Prev 1996:2:98-104.

13 Mowat DL, Wang F, Pickett W, et al. A case control study of risk factors for playground injuries in Kingston and area. Inj Prev 1998;4:39-43

14 Laforest S, Robitaille Y, Dorval D, et al. Severity of fall injuries on sand and grass in playgrounds. J Epidemiol Community Health 2000;54:475-7.
15 Macarthur C, Hu X, Wesson DE, et al. Risk factors for severe playground injuries associated with falls from playground equipment. Accident Analysis and Prevention 2000;32:377-82.

16 Petridou E, Sibert J, Dedoukou X, et al. Injuries in public and private playgrounds: the relative contribution of structural, equipment and human factors. Acta Paediatr 2002:91:691-7.

17 Rivers RP, Boyd RD, Baderman H. Falls from equipment as a cause of playground injury. Community Health 1978;9:178-9.

18 Frost J. Making playgrounds safe for children. Young Child July 1979:23-30

19 Oliver TI, MacFarlane JP, Haigh JC, et al. Playground equipment and accidents. Aust Paediatr J 1981;17:100-3

20 Christensen S. Accidents with playground equipment 3. Accidental falls. Ugeskr Laeger 1982; 144:3568-71

21 Boyce W, Sobolewski S, Sprunger LW, et al. Playground injuries in a large, urban school district. American Journal of Public Health 1984;74:987-6.

22 Ball D, King KL. Playground injuries; a scientific appraisal of popular concerns. J R Soc Health 1991:111:134-7.

23 Edwards $\mathbf{D}$. Tarzan swings. A dangerous new epidemic. Br J Sports Med 1991;25: 168-9.

24 Bond M. The risk of childhood injury on Boston's playground equipment and surfaces. Am J Public Health 1993:83:5.

25 Mott A, Evans R, Rolfe K, et al. Patterns of injuries to children on public playgrounds. Arch Dis Child 1994;71:328-30.

26 Briss PA, Sacks JJ, Addiss DG, et al. A nationwide study of the risk of injury associated with day care center attendance. Pediatrics 1994;93:364-8

27 Lillis K. Playground injuries in children. Pediatr Emerg Care 1997;13:149-53.

28 Mack M, Hudson S, Thompson D. A descriptive analysis of children's playground injuries in the United States, 1990-4. Inj Prev 1997;3:100-3.

29 Mayr J. Playground accidents. Acta Paediatr 1995;84:573-6.

30 Chalmers D. Playground injury: the kids are still falling for it. Children's Issues $1999 \cdot 3(2) \cdot 29-32$
31 Waltzman ML, Shannon M, Bowen AP, et al Monkeybar injuries: complications of play. Pediatrics 1999;103:58.

32 Bernardo LM. Playground injuries in children. A review and Pennsylvania trauma centre experience. J Soc Paediatr Nurses 2001 ;6:1 1-20.

33 CPSC. Playground injuries treated in US hospital emergency rooms. CPSC, 2001

34 Norton C, Rolfe K, Morris S, et al. How common are head injury and fracture to children in playgrounds with modern safety changes? An epidemiological study.

35 Robinovitch SN, Chiu J. Surface stiffness affects impact force during a fall on the outstretched hand. J Orthop Res 1998;16:309-13.

36 ASTM. F1292-95 (American Society for Testing Materials) Standard Specification for Impact Attenuation of Surface Systems under and around Playground Equipment. Philadelphia: ASTM, 1995.

37 Faber MM. Massive subgaleal hemorrhage: a hazard of playground swings. Clin Pediatr 1976; 15:384-5.

38 Nixon J, Acton C, Wallis B, et al. Injury and frequency of use of playground equipment in public schools and parks in Brisbane Australia. Inj Prev 2003;9:210-13.

39 Torrence M. Why play? Montessori Life 2001;13:20-1.

40 Hudson S, Thompson D, Mack M. Safe playgrounds: increased challenges, increased risks. Dimensions of Early Childhood 2001;29:18-23.

41 http://www.kidsource.com/kidsource/content4/ school.recess.html.

42 Nixon J. Death during play: a study of playground and recreation deaths in children. BMJ 1981;283:410

43 Lam LT. Children at play: the death and injury pattern in NSW, July 1990-June 1994. J Paediat Child Health 1999:35:572-7.

44 CPSC. Hazard identification and analysis report. Public playground equipment. Washington: DC, CPSC, 1979.

45 Mack MG. A descriptive analysis of children's playground injuries in the USA 1990-4. Inj Prev 1997;3:100-3.

46 Tinsworth D. Injuries and deaths associated with playground equipment. CPSC, 2001

47 Tan Amy. Personal communication, 2001. 